\title{
Wild bee distribution near forested landscapes is dependent on successional state
}

\author{
Katherine A. Odanaka $a^{1,2}$ and Sandra M. Rehan ${ }^{1,2^{*}}$
}

\begin{abstract}
Background: Forested landscapes are valuable sources of ecosystem services especially in areas dedicated to intense agricultural activities. Distance from forest margin is known to influence the wild bee community in the landscape surrounding forested patches. Yet little is known regarding how bee communities distribute themselves in landscapes that exhibit different forest successional states.

Methods: We examined how land use type and distance from the forest edge affect the abundance and richness of the wild bee community across four forest successional states. Bees were collected in sites representing four stages of forest succession and analyzed using generalized linear mixed models with negative binomial distributions.

Results: Wild bee diversity is reduced in forested environments that maintain dense stands of trees and high canopy cover. Additionally, distance from the forest edge was an important factor determining wild bee distribution in successional stages adjacent to forest edges. Furthermore, we found that bees maintain high specificity for distinct successional states and distances.

Conclusions: Our results demonstrate how different successional stages can harbor different bee species and highlight the ability of microhabitats to act as reservoirs of bee diversity in and around forest margins. Furthermore, we found that maximizing successional patchiness across forested landscapes increases the amount of available habitat that can support a diverse suite of bees with different nesting biologies and behaviors.
\end{abstract}

Keywords: Pollinator, Forest margin, Bee habitat, Nesting biology, Wild bees

\section{Background}

Within the past 10 years, our collective knowledge regarding the biology, behavior, and evolutionary history of wild bees has greatly expanded. As central place foragers, bees are highly dependent on the availability of resources near their nest and without access to acceptable forage or nesting risk extirpation from these environments (Greenleaf et al. 2007; Williams and Kremen 2007; Ferreira et al. 2013; Blaauw and Isaacs 2014). Human mediated environmental change is now a constant

\footnotetext{
* Correspondence: sandra.rehan@gmail.com

${ }^{1}$ Department of Biological Sciences, University of New Hampshire, Durham, $\mathrm{NH}$, USA

${ }^{2}$ Department of Biology, York University, Toronto, ON, Canada
}

process and modifications in land use, especially agricultural expansion, are among the most damaging to wild bee communities, as former habitat and nesting resources are converted to pasture and farm land (Williams and Kremen 2007; Quintero et al. 2009; M'Gonigle et al. 2015; Newbold et al. 2015; Mallinger et al. 2016; Harrison et al. 2017). However, there are contrasting reactions by different bee communities to the varied types of landscape modification (such as but not limited to urbanization, agricultural expansion, or setting aside land for conservation) indicating that wild bees are responding to landscape level changes in local resources (Kremen et al. 2002; Bengtsson et al. 2005; Morandin and Winston 2005; Williams and Kremen 2007;

\section{Springer Open}

(c) The Author(s). 2020 Open Access This article is licensed under a Creative Commons Attribution 4.0 International License, which permits use, sharing, adaptation, distribution and reproduction in any medium or format, as long as you give appropriate credit to the original author(s) and the source, provide a link to the Creative Commons licence, and indicate if changes were made. The images or other third party material in this article are included in the article's Creative Commons licence, unless indicated otherwise in a credit line to the material. If material is not included in the article's Creative Commons licence and your intended use is not permitted by statutory regulation or exceeds the permitted use, you will need to obtain permission directly from the copyright holder. To view a copy of this licence, visit http://creativecommons.org/licenses/by/4.0/. 
Potts et al. 2010; Power and Stout 2011; Winfree et al. 2011; Senapathi et al. 2015; Tucker and Rehan 2018). Furthermore, these varied reactions are largely dictated by biological traits (Biesmeijer et al. 2006; Williams et al. 2010; Bartomeus et al. 2013; Tucker and Rehan 2018) and certain traits for nesting (stem and cavity) and behavior (cleptoparasitism) constrain certain bee guilds to specific environments (Tscharntke et al. 1998; Sheffield et al. 2013).

Forested environments, including forest margins, provide ample resources that bees may not find in agriculturally intensive areas. This includes spring foraging sources, such as understory flowers and herbaceous plants, as well as nesting habitats in tree cavities and dead broken sticks and in bare ground (Aizen and Feinsinger 1994; De Marco and Coelho 2004; Taki et al. 2007; Winfree et al. 2007; Farwig et al. 2009; Taki et al. 2013; Bailey et al. 2014; Hanula et al. 2015; Joshi et al. 2016). Additionally, forests and forest margins provide many important ecosystem services, including the exportation of beneficial arthropods into surrounding areas (Decocq et al. 2016). Prior research has indicated that farms located close to forest margins have increased pollination and yield as they benefit from the movement of bees and other pollinators from the forest environment to the farms in search of forage (Blanche et al. 2006; Mitchell et al. 2014). The effect of forests and other seminatural areas exporting these critical pollination services has been shown in both tropical (Ricketts 2004; Ferreira et al. 2015) and temperate regions (Watson et al. 2011; Schüepp et al. 2013; Bailey et al. 2014). Furthermore, as distance from forest margins increases, pollination and yield on farms decrease, demonstrating how forest margins influence pollinator contribution near agricultural landscapes (De Marco and Coelho 2004; Chacoff and Aizen 2006; Carvalheiro et al. 2010; Mitchell et al. 2014). Although bees are known to be capable of flying hundreds of meters (Gathmann \& Tscharntke 2002), this may be an exception as bees were found to forage much closer to their nests despite having large foraging distances (Zurbuchen et al. 2010a, 2010b). If this is the case, subtle differences in where bees distribute themselves from a forest edge could be detected at finer scales, yet this remains largely unexplored.

Although forests and forest margins remain an important resource for wild bees, not all forested environments are able to support abundant and diverse bee communities, and this largely depends upon the stage of succession it is currently in. Research has focused on either the early or late stages of forest succession and those phases that lie in between have often been ignored. Mature forests (late stage succession), characterized by old growth and containing closed canopies, are less favorable to bees than forests in earlier stages of succession (Taki et al. 2007;
Swanson et al. 2011; Hanula et al. 2015). These earlier successional stages, which emulate the grassland habitats favorable for bees, are critical for the survival of solitary native bee populations as they provide essential floral resources and nesting habitat (Taki et al. 2013; Hanula et al. 2015; Roberts et al. 2017). Environments that are able to maintain states of early forest succession, through various means such as fires, grazing, or management will often have a more diverse and abundant native bee population (Potts et al. 2003a, b; Rubene et al. 2015; Kimoto et al. 2012; Noy-Meir 1995; Vulliamy et al. 2006). As forests continue to age and mature, shifts in the bee community occur and are dictated by various functional traits such as their behavior or nesting; solitary species give way to social species and ground nesters decline overall (Taki et al. 2013; Hanula et al. 2015; Rubene et al. 2015). However, little is currently known regarding how forests in the midstage of succession affect wild bee populations or the extent of how functional traits dictate where wild bees distribute themselves across these mid successional stages.

Wild bee populations continue to decline while knowledge of their habitat requirements remain poorly documented (Winfree 2010; Burkle et al. 2013; Kerr et al. 2015), resulting in a need for understanding how forest successional stages influence and shape bee communities. Deeper insight into the effects of forest succession and habitat requirements can ultimately inform different agricultural management schemes that can double as a means of wild bee conservation. We examined the effects of four unique stages of forest succession in order to 1 ) investigate the effects of successional stage and distance from forest margins on wild bee abundance and richness, 2) identify how nesting and behavioral traits create specificity for wild bee species in different successional stages, and 3) describe the wild bee community in New England forest systems for the first time.

\section{Methods \\ Study sites and sampling}

This study was conducted in Strafford County, New Hampshire $\left(43.2383^{\circ} \mathrm{N}, 71.0236^{\circ} \mathrm{W}\right)$. Collection locations were in and around mixed eastern hemlock (Tsuga canadensis) and white pine (Pinus strobus) forests. Wild bees were sampled every 2 weeks starting the first week in May through the end of September 2017. Four different forest successional stages (clear-cut $=$ forest after disturbance; closed canopy = pine and hemlock mixed forest with no canopy gaps; pasture $=$ initial plant colonization of the gap; silvopasture = pine only and canopy gaps between trees), were surveyed including: closed canopy forest, clear-cut where trees had been completely removed with $0 \%$ canopy cover, silvopasture where selected trees were removed to allow 30\% canopy cover for cattle to graze between the remaining trees, and 
pasture adjacent to forests. Both the clear-cut and silvopasture were created in 2015. Each rectangular site was approximately 1 hectare in area and all had at least one edge that was shared with the surrounding closed canopy forest. Pastures were mowed monthly and had no canopy cover. Ten cows were released at each of the pasture, silvopasture and clear-cut biweekly (alternating weeks to bee collection). Each site represented one successional stage and had three replicate $120 \mathrm{~m}$ transects; one of each transects were located at 10, 20, and $30 \mathrm{~m}$ from forest edges into each site. These transects were standardized to the forest edge so that 10,20 , or $30 \mathrm{~m}$ from the forest edge was the same distance regardless of the successional type.

We collected bees using colored pan traps that were either blue, white, or yellow following standard procedure (Tucker and Rehan 2016; 2018). We placed twelve pan traps $(7-\mathrm{cm}$ diameter, $100 \mathrm{~mL}$ ) alternating in blue, white, yellow pattern on the ground along each $120-\mathrm{m}$ transect allowing for $10 \mathrm{~m}$ between each cup and filled each one with soapy water. Traps were deployed before $8 \mathrm{AM}$ and were collected the same day after $4 \mathrm{PM}$, allowing for a total of $8 \mathrm{~h}$ collection. When emptying pan traps, contents of each trap were poured through a sieve and any collected specimens were placed in a vial containing $70 \%$ ethanol and a collection tag. Additionally, we recognize that pan traps have been shown to be biased against social and larger bee species, and are particularly favorable to those in the Halictidae (Droege et al. 2010).

\section{Bee identification}

Following the protocols in Droege (2015) we washed bee specimens and dried them with a hair drier. Once dry, specimens were then pinned, labeled with relevant location information and a unique QR code, and identified to species using online keys found on Discover Life (http://www.discoverlife.org/) as well as previously published taxonomic keys (Mitchell 1960, 1962; Gibbs 2011; Rehan and Sheffield 2011; Gibbs et al. 2013; all specimens are housed in the Rehan Lab at York University). After identification, we grouped species by their behavior type (social, solitary, cleptoparasitic) and their nesting biology (ground, stem). Bees that were classified as preferring only cavities or alternating between stems and cavities were grouped into the stems category. For behavior, bees exhibiting communal behavior were grouped into the solitary category (Matteson et al. 2008; Ascher et al. 2014; Selfridge et al. 2017). A list of all bees in this study, including their behavior and nesting biology, can be found in the supplement (S1).

\section{Statistical analyses}

Similarity coefficients and initial rarefactions were completed for each of the successional states to determine sampling adequacy (S2, S3). We then used generalized linear mixed models with negative binomial distribution to analyze the effects of forest distance and successional type on wild bee abundance and richness (Zuur et al. 2007). Both collection month and distance nested within site were used as random effect variables in our models. Fixed variables included site, distance from the forest edge, behavior type, and nesting biology. Analyses of deviance using type II Wald chi square tests were then conducted on our models in order to test for overall significance of treatments; followed by post hoc Tukey tests. All statistical analyses were conducted using $R$ ver. (3.5.2) ( $\mathrm{R}$ Core Team) and the packages 'multcomp' (Hothorn et al. 2008), iNEXT (Chao et al. 2014; Hsieh et al. 2016), vegan (Oksanen et al. 2013) and lme4 (Bates et al. 2015).

\section{Results}

A total of 297 bees, representing 63 species and 18 genera were collected. The clear-cut maintained the highest total wild bee abundance (mean \pm SD; $n=114 \pm 14.5$ ), followed by the silvopasture $(n=89 \pm 13.0)$, then the pasture $(n=82 \pm 14.3)$, and finally the forest $(n=12 \pm 2.7)$. When successional states were examined individually, the clear-cut, silvopasture, and pasture all had significantly higher bee abundance than the forest $\left(X^{2}=33.85\right.$, $\mathrm{df}=3, p \leq 0.001$ ).

\section{Succession stage (forest, pasture, silvopasture, clear-cut)} Overall, species abundance differed significantly among successional stage and distances from the forest edge $\left(X^{2}=543.85, \mathrm{df}=6, p \leq 0.001\right.$; Fig. 1a). The clear-cut $(z=$ 3.321; $p=0.005)$, silvopasture $(z=5.021 ; p<0.001)$, and pasture $(z=4.481 ; p<0.001)$ all show significantly more wild bee abundance than the forest but are not different from each other. Additionally, there were significant differences in species abundance between 20 and $30 \mathrm{~m}$ $(z=-22.39 ; p<0.001)$ as well as between 10 and $30 \mathrm{~m}$ $(z=-19.46 ; p<0.001)$.

Bee species richness also differed significantly among successional states $\left(X^{2}=30.8, \mathrm{df}=3, p \leq 0.001\right)$, but not by distance $\left(X^{2}=0.05, \quad \mathrm{df}=2, \quad p=0.975\right)$. Clear-cut $(z=5.470 ; p<0.001)$, silvopasture $(z=4.230$; $p<0.001)$, and pasture $(z=4.498 ; p<0.001)$ were all significantly richer than the forest, but there was no difference in richness among the former three states. The clear-cut had the highest overall species richness $(n=38 \pm 5.3)$, the pasture and silvopasture maintained equal amounts of species richness (pasture: $n=32 \pm$ 6.4; silvopasture: $n=32 \pm 13.0$ ), while the forest had the least species richness $(n=9 \pm 1.9)$. Species richness significantly varied among successional state by distance $\left(X^{2}=456.47 \mathrm{df}=6, p \leq 0.001\right.$; Fig. $\left.1 \mathrm{~b}\right)$. 
a)

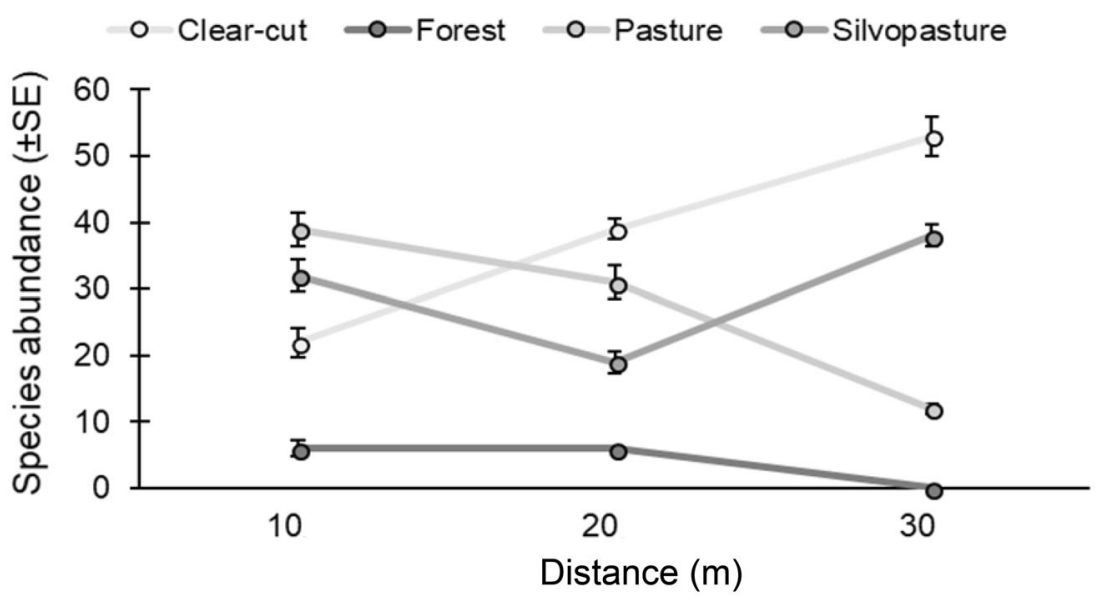

b)

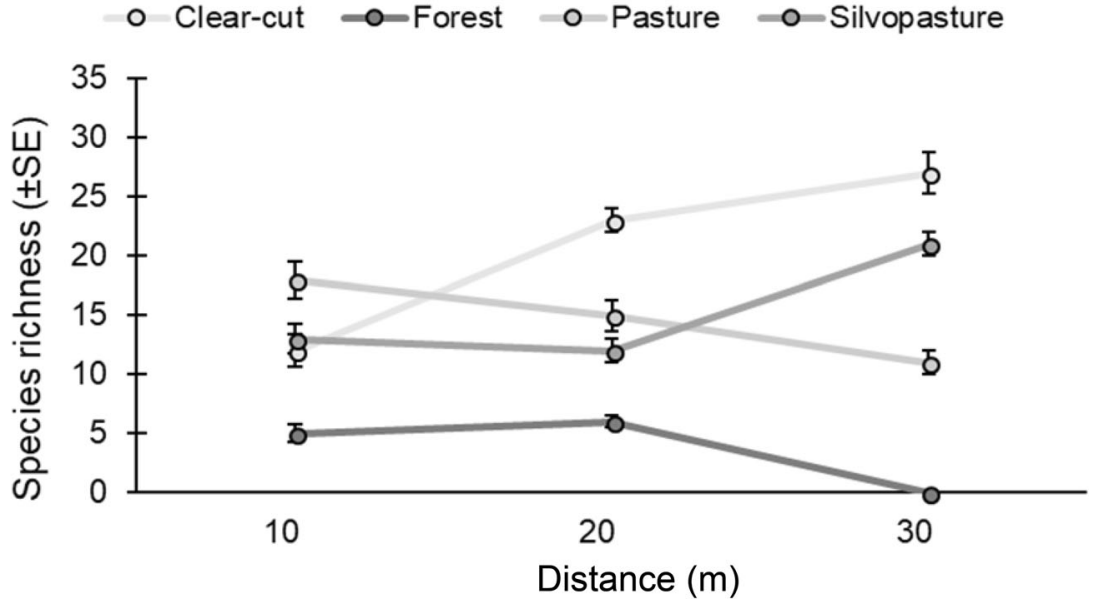

Fig. 1 Abundance (a) and richness (b) of wild bees at different distances from the forest margin across four successional states. Wild bee abundance is significantly affected by the interaction between forest successional state and forest margin distance. Species richness is also significantly influenced by the interaction between forest successional state and distance

The interaction of succession type and bee behavior on wild bee abundance was significant $\left(X^{2}=15.44, \mathrm{df}=\right.$ $6, p=0.02$; Fig. 2a). We found that solitary $(z=5.15 ; p<$ $0.001)$ and social $(z=4.82 ; p<0.001)$ species were more abundant than cleptoparasitic species. No cleptoparasites were found at the forest. Overall, solitary bees were most abundant ( $n=164 \pm 26.8)$, followed by social bees $(n=$ $122 \pm 18.1)$, then cleptoparasites $(n=11 \pm 2.3)$. Individuals from solitary species were most common in the pasture $(n=62 \pm 12.5)$ and least common in the forest ( $n=7 \pm 2.1$ ). The number of solitary individuals collected was second and third highest in the clear-cut and silvopasture respectively (clear-cut: $n=58 \pm 7.4$; silvopasture: $n=37 \pm 6.5$ ). Social bees were most common in the clear-cut $(n=51 \pm 8.5)$ and least common in the forest $(n=5 \pm 0.7)$. The silvopasture had more social individuals $(n=49 \pm 8.2)$ than the pasture $(n=17 \pm 5.4)$. Cleptoparasitic individuals were most frequent in the clear-cut sites $(n=5 \pm 1)$. Cleptoparasitic bees were equally collected within the pasture and silvopasture sites $(n=3 \pm 0.9)$.

The effect of species behavior on overall richness was significant $\left(X^{2}=60.4 ; \mathrm{df}=2, p<0.001 ;\right.$ Fig. 2b). Total richness among behavioral categories indicated that solitary bees were the most species rich $(n=32 \pm 6.4)$. Species richness of cleptoparasitic bees was almost as high as social species $(n=11 \pm 2.3$ and $n=20 \pm 4.1$ respectively). Across four different successional states, solitary bees were most diverse in the clear-cut $(n=21 \pm 3.7)$ with far fewer species collected in the forest $(n=5 \pm 1.6)$. The pasture sites were the second highest in solitary bee richness $(n=21 \pm 4.7)$ and this was followed by the silvopasture sites $(n=15 \pm 1.8)$. Social bee richness was highest in the silvopasture sites $(n=14 \pm 2.3)$, followed by clear-cut $(n=12 \pm 2.5)$, then pasture $(n=8 \pm 1.9)$, and fewest in the forest sites $(n=4 \pm 0.4)$. The clear-cut sites 
a)

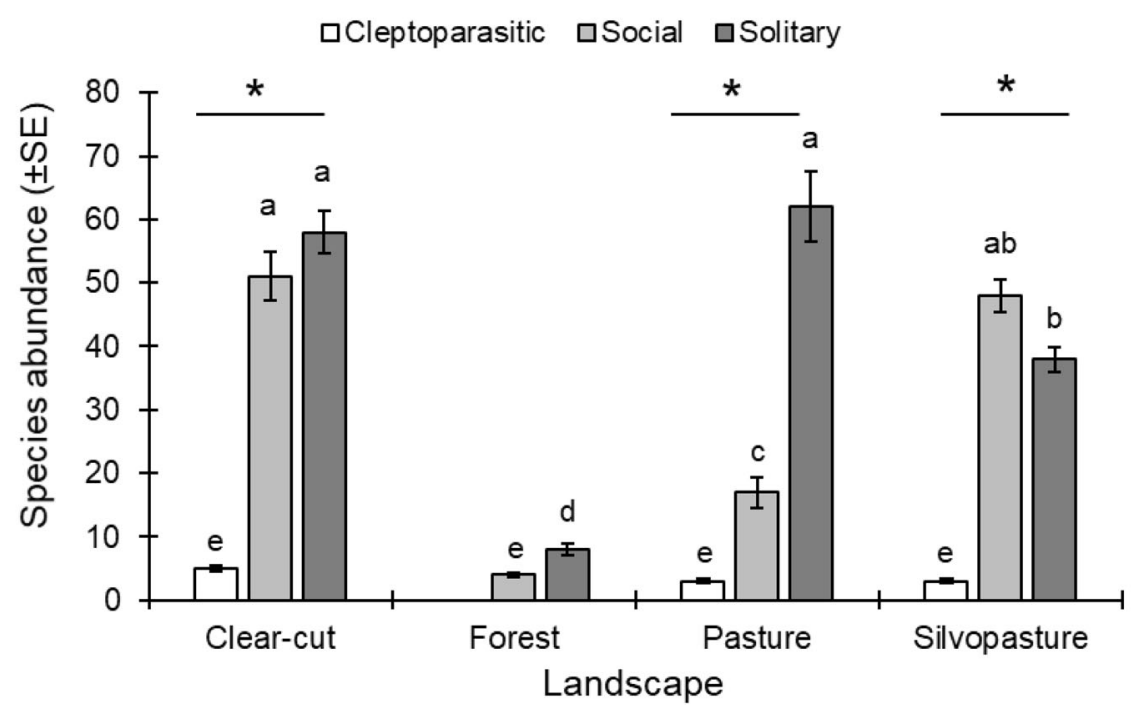

b)

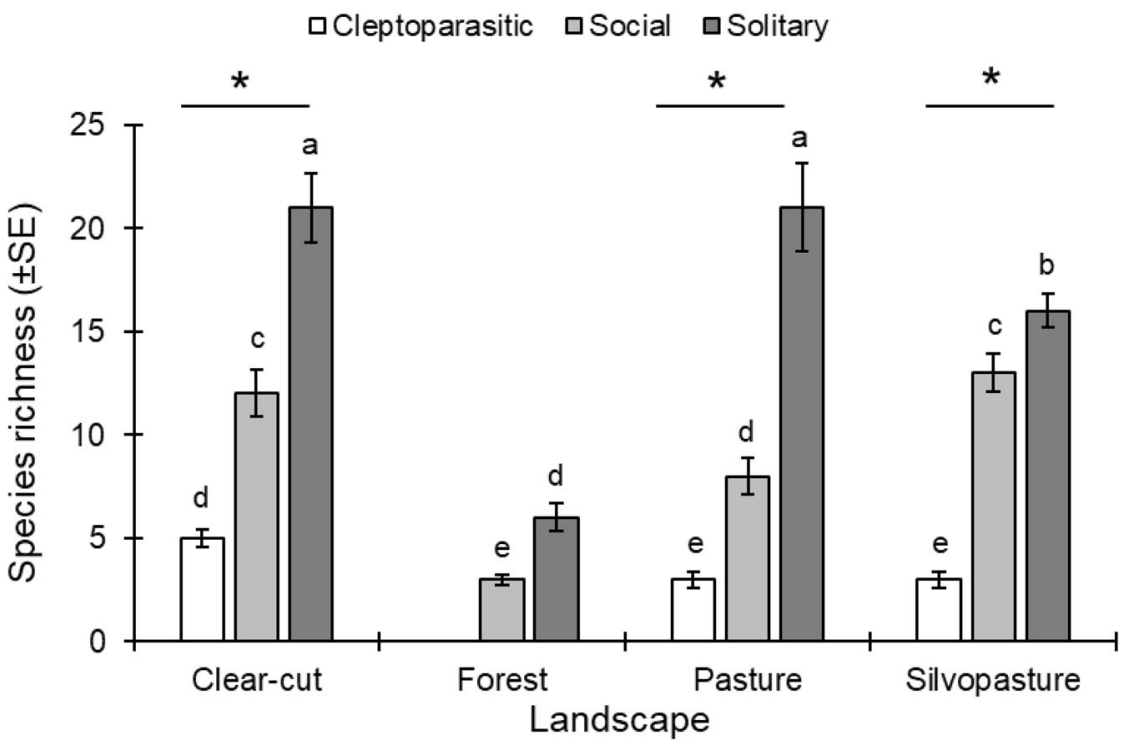

Fig. 2 Wild bee species (a) abundance and (b) richness varies significantly among successional state and behavioral classes. The forest state had the lowest diversity and abundance of wild bees, and lacked cleptoparasites. Across all remaining states, cleptoparasites were present but significantly lower in richness and abundance than both solitary and social species. $\left(^{*}\right)$ denote significance of the different successional states compared to each other while letters (a-e) denote differences between the behavioral classes across the successional states

had the most cleptoparasite species $(n=5 \pm 0.45)$. The pasture and silvopasture sites $(n=3 \pm 0.4)$ each had cleptoparasitic species, and the forest had no observed cleptoparasites.

Overall, ground nesters were more abundant $(n=$ $202 \pm 28.5)$ than stem nesters $\left(n=95 \pm 16.1 ; X^{2}=27.88\right.$; $\mathrm{df}=1 ; p \leq 0.001$ ). Successional state (forest, pasture, silvopasture, clear-cut) was also found vary significantly among nesting biologies $\left(X^{2}=27.11 ; \mathrm{df}=3 ; p<0.001\right.$; Fig. 3a). Ground $(n=76 \pm 10.3)$ and stem $(n=38 \pm 5.5)$ nesting individuals were most abundant in the clear-cut sites. Abundance of ground and stem nesters $(n=59 \pm$ 8.61, $n=30 \pm 5.0$ respectively) were second highest in the silvopasture sites. In the pasture sites, ground nesters $(n=58 \pm 9.4)$ comprised $71 \%$ of the bees captured and the remaining $29 \%$ were stem nesters $(n=24 \pm 5.4)$. Three quarters $(75 \%)$ of the individuals collected from the forest sites were ground nesters $(n=9 \pm 1.5)$ and the remaining $25 \%$ were stem nesters $(n=3 \pm 1.3)$.

Species richness varied significantly between nesting biology categories $\left(X^{2}=27.34, \mathrm{df}=1, p \leq 0.001\right.$; Fig. $\left.3 \mathrm{~b}\right)$. Overall, ground nesting bees had higher species richness 
a)

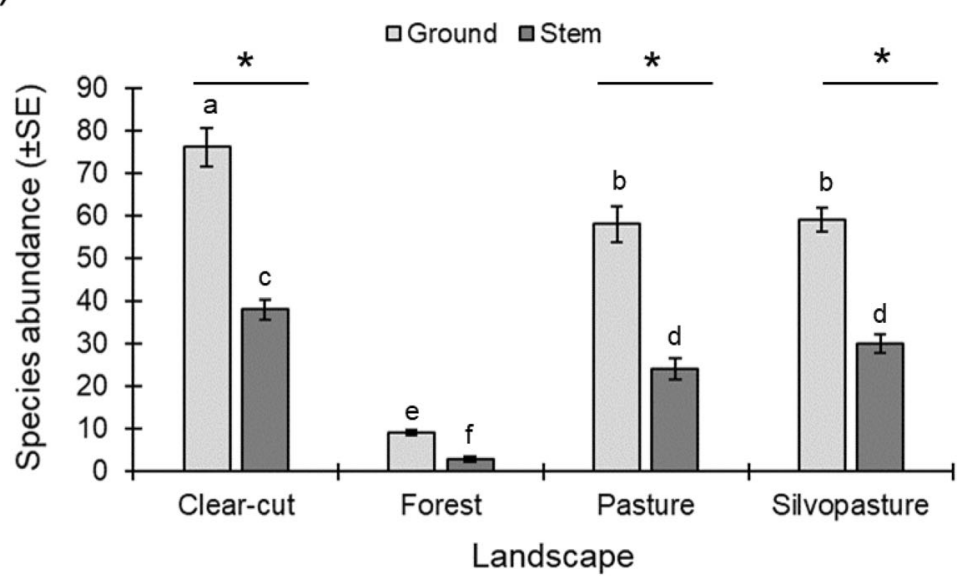

b)

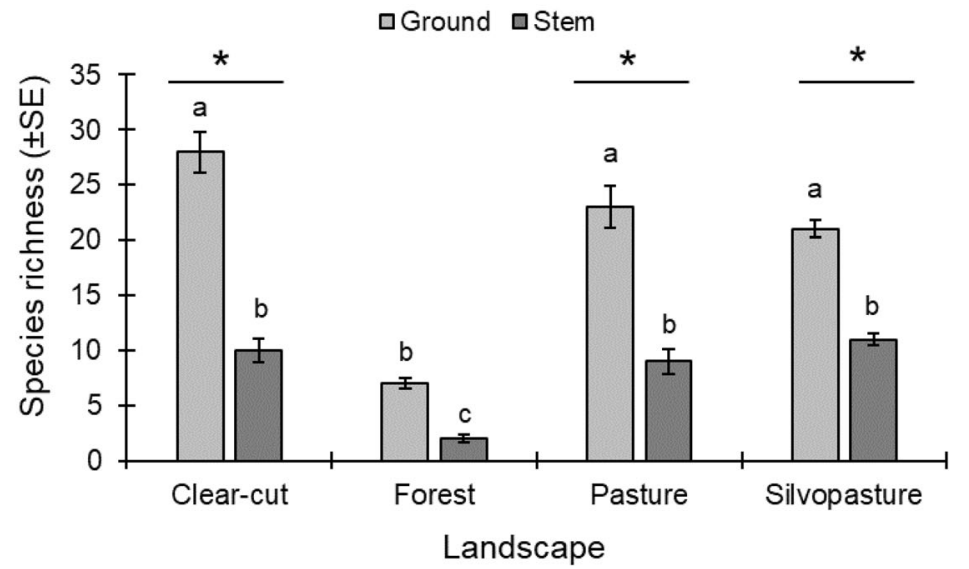

Fig. 3 Species (a) abundance and (b) richness of wild bees across successional state by nesting biology. Ground nesting bees were consistently dominant to stem nesting species across all states. $\left(^{*}\right)$ denote significance of the different states compared to each other while letters (a-f) denote differences between the two nesting biologies across the successional states

than stem nesters $(n=45 \pm 6.8$ and $n=19 \pm 4.9$ respectively; $\left.X^{2}=27.34, \mathrm{df}=1, p \leq 0.001\right)$. At the successional state level, ground nesters were most species rich within clear-cut sites $(n=28 \pm 4.2)$, followed by the pasture and silvopasture sites $(n=23 \pm 4.2, n=21 \pm 2.5$ respectively). The forest sites had the least ground nesting species richness $(n=7 \pm 1.4)$. Species richness of stem nesting bees was highest in both the clear-cut and silvopasture sites (clear-cut: $n=10 \pm 2.3$; silvopasture: $n=11 \pm 1.2$ ). The pasture sites contained the third highest $(n=9 \pm$ 2.44) and the forest sites had the least number of species $(n=2 \pm 0.9)$.

\section{Distance}

When examined together, the effects of distance on total bee abundance (both ground and stem nesters) was not significant $\left(X^{2}=0.524, \mathrm{df}=2, p=0.77\right)$. However, there was a significant interaction between nesting biology and distance to forest margins $\left(X^{2}=10.18 ; \mathrm{df}=2 ; p<\right.$ 0.006; Fig. 4a). Ground nesting bee abundance increased about $36 \%$ from 10 to $20 \mathrm{~m}$ and remained constant at $30 \mathrm{~m}$. For stem nesters, bee abundance was highest at $10 \mathrm{~m}$ and significantly lower at $20 \mathrm{~m}$. At $30 \mathrm{~m}$, stem nesting bee abundance is significantly higher than abundance at $20 \mathrm{~m}$, but also lower than bee abundance at 10 $\mathrm{m}$. Interactions between distance and nesting biology were significant $\left(X^{2}=6.64, \mathrm{df}=2, p=0.04\right.$; Fig. 4b). Ground nesting bees increased by $56 \%$ in species richness from 10 to $20 \mathrm{~m}$ and remained consistently high at $30 \mathrm{~m}$ away from forest margins. Stem nesters had a significant difference in species richness at $20 \mathrm{~m}$ from forest margins $(z=-3.164 ; p=0.002)$.

Each distance was also found to have specific bee species. Of 63 bee species, 33 (52\%) were only found at 
a)

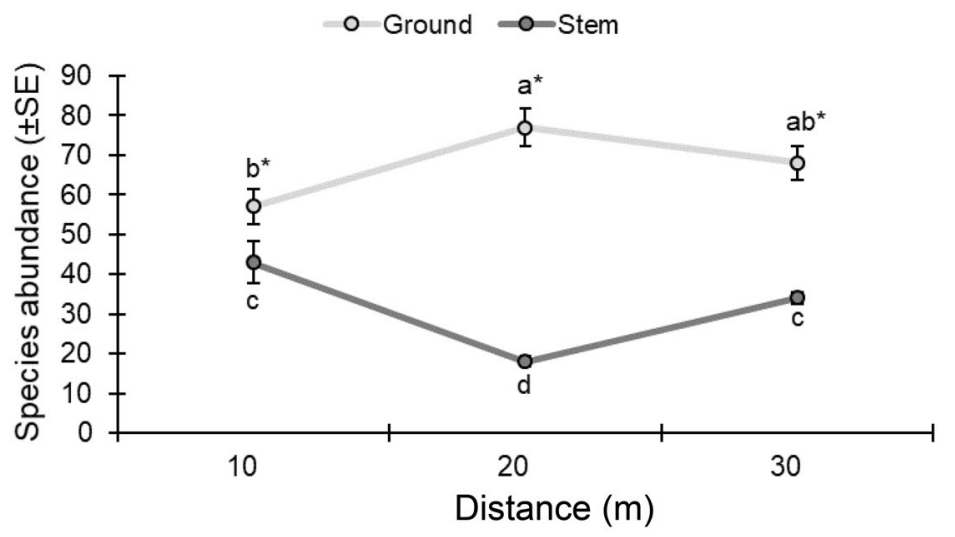

b)

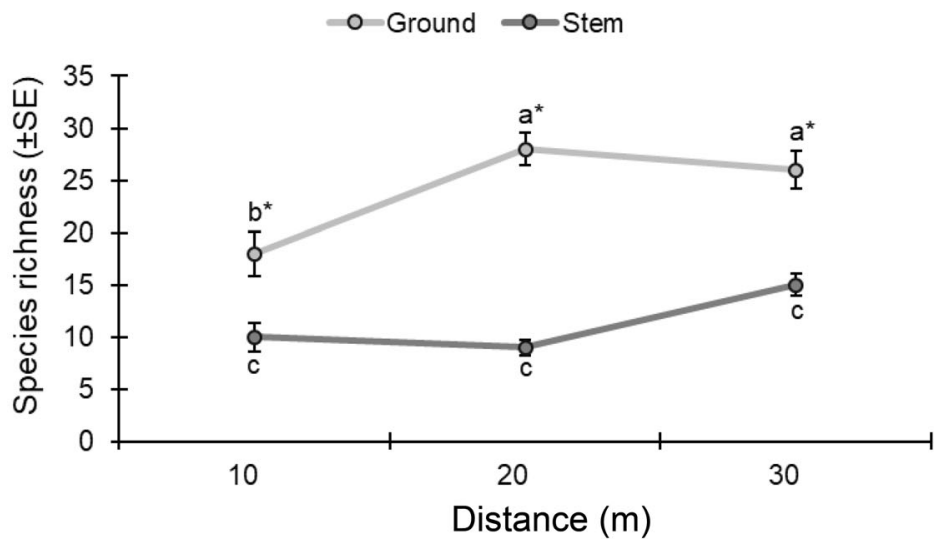

Fig. 4 Species abundance (a) and richness (b) of wild bees at different distances from the forest margin separated by nesting behavior. Ground nesting species were more abundant and diverse at distances further from forest margins. Stem nesting species were most abundant closest to forest margins. $\left(^{*}\right)$ denote overall significance of ground nesters over stem while letters $(a-d)$ denote differences of either nesting biology at each distance

certain distances from the forest margin (Table 1). Most of the distance specific species were found $30 \mathrm{~m}$ from forest margins $(n=15)$ and the least were found closest to forest margins at $10 \mathrm{~m}$ transects $(n=7)$. Of the total distance specific bees, $81 \%$ were found to be ground nesters $(n=27)$ and six of these species, all in the genus Lasioglossum, were found to be social. Half of all distance specific species were members of the family Halictidae and of those 18 species, nine occurred solely $30 \mathrm{~m}$ from forest margins. These include the only Augochlora species (A. pura) and the only Agapostemon species ( $A$. sericeus) found solely at $30 \mathrm{~m}$ from forest margins. In total, 12 of the 18 (67\%) species from the family Halictidae were from the genus Lasioglossum. Half of those Lasioglossum species $(n=6)$ were collected $20 \mathrm{~m}$ from forest margins and those species comprised $46 \%$ of the total specific species to that distance. Additionally, the only Anthidium species (A. manacatum) found in this study was captured at $20 \mathrm{~m}$ from a forest margin. Although transects $10 \mathrm{~m}$ from the forest margin contained the least specific species these include the lone specimens of Hoplitis (H. spoliata) and Melissodes (M. druriellus).

\section{Successional state specificity}

Three species were collected in all four successional states: Agapostemon virescens, Calliopsis antenniform, and Lasioglossum coriaceum. Conversely, each successional state was found to have species not collected in the other sites. In total, 34 of the $63(54 \%)$ bee species collected in this study were present in only one of the four successional states (Table 2). The clear-cut and pasture both contained the highest number of stage specific species $(n=11)$. The clear-cut contained the most halictid species, the only species of Augochlora (A. pura), and Anthidium (A. oblongatum) found in this study. The 
Table 1 Species specific to distances from forest edge. Species include five bee families (bold) and 11 genera. Nesting biology indicated with: ${ }^{*}=$ ground nesting, and $\Delta=$ stem/cavity nesting species. Social behavior indicated in parentheses with: (sol) = solitary, $(\mathrm{sOc})=$ social, and (par) = cleptoparasitic species

\begin{tabular}{|c|c|c|c|}
\hline \multirow[t]{2}{*}{ Species } & \multicolumn{3}{|l|}{ Distances from forest edge } \\
\hline & $10 \mathrm{~m}$ & $20 \mathrm{~m}$ & $30 \mathrm{~m}$ \\
\hline \multicolumn{4}{|l|}{ Andrenidae } \\
\hline Andrena & Andrena nigrihirta ${ }^{*}$ (sol) & Andrena vicina * (sol) & \\
\hline \multicolumn{4}{|l|}{ Apidae } \\
\hline Melissodes & Melissodes druriellus * (sol) & & \\
\hline \multirow[t]{3}{*}{ Nomada } & Nomada lepida * (par) & Nomada articulata * (par) & Nomada cressonii * (par) \\
\hline & & Nomada pygmaea * (par) & Nomada dreisbachi * (par) \\
\hline & & Nomada sayi * (par) & \\
\hline \multicolumn{4}{|l|}{ Colletidae } \\
\hline Hylaeus & Hylaeus affinis $\Delta$ (sol) & & Hylaeus modestus $\triangle$ (sol) \\
\hline \multicolumn{4}{|l|}{ Halictidae } \\
\hline Agapostemon & & & Agapostemon sericeus * (sol) \\
\hline Augochlora & & & Augochlora pura $\Delta$ (sol) \\
\hline \multirow[t]{6}{*}{ Lasioglossum } & Lasioglossum abanci * (soc) & Lasioglossum admirandum * (soc) & Lasioglossum bruneri * (soc) \\
\hline & & Lasioglossum hitchensi * (soc) & Lasioglossum leucozonium * (sol) \\
\hline & & Lasioglossum pilosum * (soc) & Lasioglossum lineatulum * (soc) \\
\hline & & Lasioglossum platyparium * (par) & Lasioglossum nelumbonis * (sol) \\
\hline & & Lasioglossum versans * (soc) & Lasioglossum oblongum * (soc) \\
\hline & & Lasioglossum weemsi * (soc) & \\
\hline \multirow[t]{2}{*}{ Sphecodes } & Sphecodes illinoensis * (par) & Sphecodes townesi* (par) & Sphecodes clematidis * (par) \\
\hline & & & Sphecodes ranunculi * (par) \\
\hline \multicolumn{4}{|l|}{ Megachilidae } \\
\hline Anthidium & & Anthidium oblongatum $\Delta$ (sol) & \\
\hline Hoplitis & Hoplitis spoliata $\triangle($ sol) & & \\
\hline Megachile & & Megachile latimanus* (sol) & Megachile campanulae $\Delta$ (sol) \\
\hline
\end{tabular}

pasture contained the most species of the family Megachilidae captured in one site $(n=4)$. Included in these four species were the only species of Hoplitis (H. spoliata), the only Megachile (M. companulae, M. latimanus), and one Osmia (O. albiventris) species. Furthermore, the only Melissodes (M. druriellus) was found at a pasture site.

Although the forest and silvopasture both are comprised of mixed forest, they did not have any similarities in community composition or number of stage-specific species. Only two species were found only in the forest: Andrena nigrihirta and Lasioglossum pilosum. The silvopasture however, contained ten stage-specific species, half of which were Lasioglossum species, which was the most for any successional stage and includes L. platyparium, the only social parasitic species of this genus collected in this study. The silvopasture sites also contained the most successional state specific Osmia $(n=2)$ species: $O$. atriventris and $O$. collinsiae.

\section{Discussion}

This study investigated and documented the effects of four different successional states and three different distances from forest margins on wild bee communities. Here we determined successional stage specificity among wild bees as a product of set traits such as species behavior and nesting biology. Our study reveals that wild bees in forested environments are affected by distance from forest margins and by nesting habitat. Within each successional state, we found bees assorted by their behavior and nesting biology while nesting biology alone revealed different niches at 10 versus 20 and $30 \mathrm{~m}$ from forest margins. Findings from our study further support the need for heterogeneous landscape composition to bolster diverse wild bee communities.

Succession type (forest, pasture, silvopasture, clear-cut) Wild bee behavior and nesting biology was significantly associated with successional state. We found that 
Table 2 Species specific to the four different successional states examined in this study. Species include five bee families (bold) and 11 genera. Nesting biology indicated with: ${ }^{*}=$ ground nesting, and $\Delta=$ stem/cavity nesting species. Social behavior indicated in parentheses with: $($ sol $)=$ solitary, $(\mathrm{soc})=$ social, and $($ par $)=$ cleptoparasitic species

\begin{tabular}{|c|c|c|c|c|}
\hline Species & Forest & Silvopasture & Clear-cut & Pasture \\
\hline \multicolumn{5}{|l|}{ Andrenidae } \\
\hline Andrena & Andrena nigrihirta * (sol) & & Andrena vicina ${ }^{*}($ sol) & \\
\hline \multicolumn{5}{|l|}{ Apidae } \\
\hline Melissodes & & & & Melissodes druriellus * (sol) \\
\hline \multirow[t]{2}{*}{ Nomada } & & Nomada cressonii * (par) & Nomada pygmaea * (par) & Nomada articulate * (par) \\
\hline & & Nomada dreisbachi * (par) & Nomada sayi * (par) & Nomada lepida * (par) \\
\hline \multicolumn{5}{|l|}{ Colletidae } \\
\hline Hylaeus & & Hylaeus modestus $\Delta$ (sol) & & Hylaeus affinis $\Delta$ (sol) \\
\hline \multicolumn{5}{|l|}{ Halictidae } \\
\hline Augochlora & & & Augochlora pura $\triangle(\mathrm{sol})$ & \\
\hline \multirow[t]{5}{*}{ Lasioglossum } & Lasioglossum pilosum * $(\mathrm{soc})$ & Lasioglossum coeruleum $\Delta$ (soc) & Lasioglossum bruneri ${ }^{*}$ (soc) & Lasioglossum admirandum * (soc) \\
\hline & & Lasioglossum lineatulum * (soc) & Lasioglossum weemsi * (soc) & Lasioglossum leucocomum * (soc) \\
\hline & & Lasioglossum oblongum * (soc) & & \\
\hline & & Lasioglossum platyparium * (par) & & \\
\hline & & Lasioglossum versans * (soc) & & \\
\hline \multirow[t]{3}{*}{ Sphecodes } & & & Sphecodes clematidis * (par) & Sphecodes townesi * (par) \\
\hline & & & Sphecodes illinoensis * (par) & \\
\hline & & & Sphecodes ranunculi * (par) & \\
\hline \multicolumn{5}{|l|}{ Megachilidae } \\
\hline Anthidium & & & Anthidium oblongatum $\Delta$ (sol) & \\
\hline Hoplitis & & & & Hoplitis spoliata $\Delta($ sol) \\
\hline \multirow[t]{2}{*}{ Megachile } & & & & Megachile campanulae $\Delta$ (sol) \\
\hline & & & & Megachile latimanus * (sol) \\
\hline \multirow[t]{2}{*}{ Osmia } & & Osmia atriventris $\Delta(\mathrm{sol})$ & Osmia distincta $\Delta($ sol) & Osmia albiventris $\Delta(\mathrm{sol})$ \\
\hline & & Osmia collinsiae $\Delta($ sol) & & \\
\hline
\end{tabular}

environments containing little to no canopy cover supported the most abundant and rich bee communities in comparison to the forest dominated by dense stands of trees which is consistent with previous findings (Winfree et al. 2007; Hanula et al. 2015; Roberts et al. 2017). Dense forests lack many of the resources important for bee habitat, such as nesting substrate, suitable sunlight, and consistent forage (Swanson et al. 2011; Hanula et al. 2015, 2016). This is especially critical once the spring blooming period has ended and trees begin to produce leaves which block sunlight from reaching the understory and prohibit the growth of additional forage (Taki et al. 2007; Schüepp et al. 2013). Moreover, foraging by bees and other hymenopterans is reduced in the presence of shade and thus cooler temperatures (Herrera 1995; McKinney and Goodell 2010; Polatto et al. 2014). The majority of wild bees found in the forest were solitary ground nesters and were located close to forest margins. This observation provides evidence further supporting the notion that solitary bees will build their nests at forest edges where there is less canopy shade and more open ground (Klein et al. 2003).

The pasture, clear-cut, and silvopasture states all represent different stages of deforestation allowing for insight into how wild bee populations respond to disturbance. Previous research has shown that bees respond favorably to disturbance from forested environments and will be found consistently in greater numbers where disturbance has occurred (Hanula and Horn 2011; Fiedler et al. 2012; Hudson et al. 2013). The most disturbed of our states studied were the clear-cut sites, which maintained the highest bee community abundance and species richness in this study. Since disturbance reverts sections of forest back to early stage succession, our clear-cut sites may be able to generate an abundance of essential foraging and nesting resources, which are essential for attracting and retaining populations of solitary bees (Taki et al. 2013; Roberts 
et al. 2017). Local factors, such as the availability of nesting resources, can impact wild bee community composition by increasing species diversity (Murray et al. 2012) which can explain the highly taxon and habitat specific differences in the wild bee communities found between our silvopasture and pasture sites. Both silvopasture and pasture sites had nearly equal richness and abundance of wild bees, but each successional state provided habitat to different species based on nesting biology and behavior. Where the pasture sites contained more bare ground and thus catered more towards solitary ground nesting bees, the silvopasture, which lacked exposed soil, housed more stem nesting bees and more species exhibiting social behavior.

\section{Distance}

Our results indicate that the overall distribution of wild bees across different distances near forest margins is determined by nesting biology and perhaps the availability of specific nesting resources. Bailey et al. (2014) found that distance from the forest margin was one of the most important factors in explaining variance in wild bee communities. We found that distance from forest margins explained differences in bee abundance and richness only when the community was grouped by nesting guild. Stem nesting bees were mostly found at $10 \mathrm{~m}$, while ground nesting species were much more common at 20 and $30 \mathrm{~m}$ from forest margins. These variances were likely due to the location of appropriate nesting substrate, as stems and twigs were most abundantly located closest to forest margins, while exposed bare ground increased as distance from forests increased. Furthermore, our results support research by Cane et al. (2006) and Potts et al. (2003a, b, 2005), who suggest that the availability of nesting resources exert enough pressure to shape bee communities based on their specific nesting guilds.

The effect of distance from forest margins on wild bee communities is a topic of increasing interest, especially in regards to agriculture; yet very few of these distance studies detail changes in specific bee species as distance from forest margins increase (Chacoff and Aizen 2006; Taki et al. 2007; Bailey et al. 2014; Joshi et al. 2016). Many of these studies are in agriculture settings and show overall declines in species richness and floral visitation rates as distance increases (Klein et al. 2003; Kohler et al. 2008; Carvalheiro et al. 2010; Schüepp et al. 2013). Unlike earlier distance studies, whose maximum distance from the forest edge was $100 \mathrm{~m}$ or more (Taki et al. 2007; Watson et al. 2011; Bailey et al. 2014; Joshi et al. 2016), the spatial scale of our project was much finer, focusing on 10 to $30 \mathrm{~m}$. This reduced scale allows us to detect narrower nuances in the distribution of wild bees across shorter distances and examine how species composition changes as distance increases. We found that over half of recorded bee species were distance specific and that distance specificity is a product of bee nesting biology. Our conclusion further corroborates the notion that nesting resources are able to shape bee communities (Potts et al. 2005; Cane et al. 2006), but our result suggest this might occur at a much finer scale. Unlike nesting biology, we did not detect clear distance specificity among behavioral categories. Prior distance analyses that differentiate between the bee behavior classes focus mainly on honey bees or bumble bees or both as social representatives (Bailey et al. 2014; Joshi et al. 2016). Consequently, little is currently known regarding the responses of social species outside of the Apidae, such as those in the genus Lasioglossum, to distances from forest margins. Future studies documenting all species are needed, especially to gain insights into the habitat requirements of the greatly understudied social halictids and the wide range of speciose solitary bees.

\section{Successional state specificity}

Our results corroborate previous findings regarding the importance of heterogeneous landscapes for diverse wild bee populations in larger ecosystems, especially agroecosystems where homogeneous landscapes are common (Steckel et al. 2014; Mallinger et al. 2016; Tucker and Rehan 2018). Both Tucker and Rehan (2018) and Svensson et al. (2000) found that landscape specificity affects species within genera differently and our results mirror those findings. This effect can best be seen in the genus Lasioglossum, the most species rich genus captured in our study, where half of the species captured (10 spp.) were specific to one type of landscape. As indicated by our data, loss of heterogeneous landscapes (such as different successional states across a largely forested landscapes) may extirpate those species that require unique habitats, thus reducing wild bee diversity and community resilience to environmental change. The implementation of wildflower plantings, hedgerows and increasing seminatural habitats within homogeneous landscapes provides a way to generate the heterogeneous environment that may offer the refuge for those bees that are landscape specific (Steffan-Dewenter et al. 2002; Williams and Kremen 2007; Le Féon et al. 2010; Kremen and M'Gonigle 2015; Decocq et al. 2016). Due to the regional nature of this study, future research is needed in order to replicate and compare our findings across New England and beyond.

\section{Conclusions}

It is critical to understand how habitat requirements influence wild bee distribution within landscapes so that decisions regarding conservation will have the most positive impact. We found that overall wild bee 
abundance and richness in forested landscapes exhibiting multiple states of different forest successional stages were influenced by the amount of canopy cover present. Our results are consistent with the findings of other studies in forested environments which indicate the negative relationship between wild bee abundance and diversity and canopy cover (Grundel et al. 2010; Roberts et al. 2017; Breland et al. 2018; Odanaka et al. 2020). Successional states that maintained higher bee abundance and richness had less canopy and abundant bare ground. Our data further indicates that wild bee conservation practices and current means of forest management could be complimentary. Both aim to reduce tree density in forested areas, while opening the canopy and raising understory temperatures, which benefit both wild bee communities and understory plants (Taki et al. 2013, 2007; Hudson et al. 2013; Hanula et al. 2015). Reduction of tree density, through managed burns or manual thinning, exposes more ground, allowing for usage by ground nesting bees (Hanula et al. 2015, 2016). Our data suggests that maintaining heterogenous landscapes through supporting multiple successional states aids in promoting wild bee diversity especially in areas that are prone to lacking diversity, such as agriculturally dominant areas.

\section{Supplementary information}

Supplementary information accompanies this paper at https://doi.org/10. 1186/s40663-020-00241-4.

\section{Additional file 1}

\section{Acknowledgements}

We thank Jacob Withee, Wyatt Shell, Molly Jacobson, Stephanie Gardner, Erika Tucker, and Minna Mathiasson (University of New Hampshire) for their help with fieldwork, specimen processing, identifications and databasing.

\section{Authors' contributions}

KAO analyzed data and drafted manuscript; SMR conceived study, assisted with data analyses and edited manuscript. The authors read and approved the final manuscript.

\section{Funding}

USDA National Institute of Food and Agriculture Hatch Project 1004515 and Foundation for Food and Agriculture Research Pollinator Health fund 549038.

\section{Availability of data and materials}

All specimens are housed in the Rehan lab at York University, data and specimens will be made available upon request.

\section{Ethics approval and consent to participate}

Not applicable.

\section{Consent for publication}

Not applicable.

\section{Competing interests}

The authors declare that they have no competing interests.
Received: 8 January 2020 Accepted: 7 April 2020

Published online: 23 April 2020

\section{References}

Aizen MA, Feinsinger P (1994) Forest fragmentation, pollination, and plant reproduction in a Chaco dry forest, Argentina. Ecology 75:330-351

Ascher JS, Kornbluth S, Goelet RG (2014) Bees (Hymenoptera: Apoidea: Anthophila) of Gardiners Island, Suffolk County, New York. Northeast Nat 21: 47-71

Bailey S, Requier F, Nusillard B, Roberts SPM, Potts SG, Bouget C (2014) Distance from forest edge affects bee pollinators in oilseed rape fields. Ecol Evol 4: $370-380$

Bartomeus I, Ascher JS, Gibbs J, Danforth BN, Wagner DL, Hedtke, SM, Winfree, R (2013) Historical changes in northeastern US bee pollinators related to shared ecological traits. PNAS 110:4656-4660.

Bates D, Mächler M, Bolker BM, Walker SC (2015) Fitting linear mixed-effects models using Ime4. J Stat Softw. https://doi.org/10.18637/jss.v067.01

Bengtsson J, Ahnström J, Weibull AC (2005) The effects of organic agriculture on biodiversity and abundance: a meta-analysis. J Appl Ecol 42:261-269

Biesmeijer JC, Roberts SPM, Reemer M, Ohlemuller R, Edwards M, Peeters T, Schaffers AP, Potts SG, Kleukers R, Thomas CD, Settele J, Kunin WE (2006) Parallel declines in pollinators and insect-pollinated plants in Britain and the Netherlands. Science 313:351-354.

Blaauw BR, Isaacs R (2014) Flower plantings increase wild bee abundance and the pollination services provided to a pollination-dependent crop. J Appl Ecol 51:890-898

Blanche KR, Ludwig JA, Cunningham SA (2006) Proximity to rainforest enhances pollination and fruit set in orchards. J Appl Ecol 43:1182-1187

Breland S, Turley NE, Gibbs J, Isaacs R, Brudvig LA (2018) Restoration increases bee abundance and richness but not pollination in remnant and postagricultural woodlands. Ecosphere 9:e02435

Burkle LA, Marlin JC, Knight TM (2013) Plant-pollinator interactions over 120 years: loss of species, co-occurrence, and function. Science 339:1611-1615

Cane JH, Minckley RL, Kervin LJ, Roulston TH, Neal M (2006) Complex responses within a desert bee guild (Hymenoptera : Apiformes) to urban habitat fragmentation. Ecol Appl 16:632-644

Carvalheiro LG, Seymour CL, Veldtman R, Nicolson SW (2010) Pollination services decline with distance from natural habitat even in biodiversity-rich areas. J Appl Ecol 47:810-820

Chacoff NP, Aizen MA (2006) Edge effects on flower-visiting insects in grapefruit plantations bordering premontane subtropical forest. J Appl Ecol 43:18-27

Chao A, Gotelli NJ, Hsieh TC, Sander EL, Ma KH, Colwell RK, Ellison AM (2014) Rarefaction and extrapolation with Hill numbers: a framework for sampling and estimation in species diversity studies. Ecol Monogr 84:45-67

De Marco P, Coelho FM (2004) Services performed by the ecosystem: Forest remnants influence agricultural cultures' pollination and production. Biodivers Conserv 13:1245-1255

Decocq G, Andrieu E, Brunet J, Chabrerie O, De Frenne P, De Smedt P, Deconchat M, Diekmann M, Ehrmann S, Giffard B, Mifsud EG, Hansen K, Hermy M, Kolb A, Lenoir J, Liira J, Moldan F, Prokofieva I, Rosenqvist L, Varela E, Valdés A, Verheyen K, Wulf M (2016) Ecosystem services from small forest patches in agricultural landscapes. Curr For Reports 2:30-44

Droege S (2015) The very handy manual : how to catch and identify bees and manage a collection. USGS Nativ Bee Invent Monit Lab 1-65

Droege S, Tepedino VJ, LeBuhn G, Link W, Minckley RL, Chen Q, Conrad C (2010) Spatial patterns of bee captures in North American bowl trapping surveys. Insect Conserv Diver 3:15-23.

Farwig N, Bailey D, Bochud E, Herrmann JD, Kindler E, Reusser N, Schüepp C, Schmidt-Entling MH (2009) Isolation from forest reduces pollination, seed predation and insect scavenging in Swiss farmland. Landsc Ecol 24:919-927

Ferreira PA, Boscolo D, Carvalheiro LG, Biesmeijer JC, Rocha PLB, Viana BF (2015) Responses of bees to habitat loss in fragmented landscapes of Brazilian Atlantic rainforest. Landsc Ecol 30:2067-2078

Ferreira PA, Boscolo D, Viana BF (2013) What do we know about the effects of landscape changes on plant-pollinator interaction networks? Ecol Indic 31: 35-40

Fiedler AK, Landis DA, Arduser M (2012) Rapid shift in pollinator communities following invasive species removal. Restor Ecol 20:593-602

Gathmann A, Tscharntke T (2002) Foraging ranges of solitary bees. J Anim Ecol 7: $757-764$ 
Gibbs J (2011) Revision of the metallic Lasioglossum (Dialictus) of eastern North America (Hymenoptera: Halictidae: Halictini). Zootaxa 216:1-216

Gibbs J, Packer L, Dumesh S, Danforth BN (2013) Revision and reclassification of Lasioglossum (Evylaeus), L. (Hemihalictus) and L. (Sphecodogastra) in eastern North America (Hymenoptera: Apoidea: Halictidae). Zootaxa 3672:1-117

Greenleaf SS, Williams NM, Winfree R, Kremen C (2007) Bee foraging ranges and their relationship to body size. Oecologia 153:589-596

Grundel R, Jean RP, Frohnapple K, Glowacki GA, Scott PE, Pavlovic NB (2010) Floral and nesting resources, habitat structure, and fire influence bee distribution across an open-forest gradient. Ecol Appl 20:1678-1692

Hanula JL, Horn S (2011) Removing an invasive shrub (Chinese privet) increases native bee diversity and abundance in riparian forests of the southeastern United States. Insect Conserv Divers 4:275-283

Hanula JL, Horn S, O'Brien JJ (2015) Have changing forests conditions contributed to pollinator decline in the southeastern United States? For Ecol Manag 348:142-152

Hanula JL, Ulyshen MD, Horn S (2016) Conserving pollinators in north American forests: a review. Nat Areas J 36:427-439

Harrison T, Gibbs J, Winfree R (2017) Anthropogenic landscapes support fewer rare bee species. Landsc Ecol 34:1-12

Herrera CM (1995) Microclimate and individual variation in pollinators: flowering plants are more than their flowers. Ecology 76:1516-1524

Hothorn T, Bretz F, Westfall P (2008) Simultaneous inference in general parametric models. Biom J 50:346-353

Hsieh TC, Ma KH, Chao A (2016) iNEXT: an R package for rarefaction and extrapolation of species diversity (Hill numbers). Methods Ecol Evol 7:14511456

Hudson JR, Hanula JL, Horn S (2013) Removing Chinese privet from riparian forests still benefits pollinators five years later. Biol Conserv 167:355-362

Joshi NK, Otieno M, Rajotte EG, Fleischer SJ, Biddinger DJ (2016) Proximity to woodland and landscape structure drives pollinator visitation in apple orchard ecosystem. Front Ecol Evol 4:1-9

Kerr JT, Pindar A, Galpern P, Packer L, Potts SG, Roberts SM, Rasmont P, Schweiger O, Colla SR, Richardson LL, Wagner DL, Gall LF, Sikes DS, Pantoja A (2015) Climate change impacts on bumblebees converge across continents. Science 349:177-180

Kimoto C, Debano SJ, Thorp RW, Taylor RV, Schmalz H, Delcurto T, Johnson T, Kennedy PL, Rao S (2012) Short-term responses of native bees to livestock and implications for managing ecosystem services in grasslands. Ecosphere 3:1-19

Klein AM, Steffan-Dewenter I, Tscharntke T (2003) Fruit set of highland coffee increases with the diversity of pollinating bees. Proc R Soc B Biol Sci 270 955-961

Kohler F, Verhulst J, Van Klink R, Kleijn D (2008) At what spatial scale do highquality habitats enhance the diversity of forbs and pollinators in intensively farmed landscapes? J Appl Ecol 45:753-762

Kremen C, M'Gonigle LK (2015) Small-scale restoration in intensive agricultural landscapes supports more specialized and less mobile pollinator species. J Appl Ecol 52:602-610

Kremen C, Williams NM, Thorp RW (2002) Crop pollination from native bees at risk from agricultural intensification. Proc Natl Acad Sci 99:16812-16816

Le Féon V, Schermann-Legionnet A, Delettre Y, Aviron S, Billeter R, Bugter R, Hendrickx F, Burel F (2010) Intensification of agriculture, landscape composition and wild bee communities: a large scale study in four European countries. Agric Ecosyst Environ 137:143-150

M'Gonigle LK, Ponisio LC, Cutler K, Kremen C (2015) Habitat restoration promotes pollinator persistence and colonization in intensively managed agriculture. Ecol Appl 25:1557-1565

Mallinger RE, Gibbs J, Gratton C (2016) Diverse landscapes have a higher abundance and species richness of spring wild bees by providing complementary floral resources over bees' foraging periods. Landsc Ecol 31 1523-1535

Matteson KC, Ascher JS, Langellotto GA (2008) Bee richness and abundance in New York City urban gardens. Ann Entomol Soc Am 101:140-150

McKinney AM, Goodell K (2010) Shading by invasive shrub reduces seed production and pollinator services in a native herb. Biol Invasions 12:27512763

Mitchell MGE, Bennett EM, Gonzalez A (2014) Forest fragments modulate the provision of multiple ecosystem services. J Appl Ecol 51:909-918

Mitchell TB (1960) Bees of the eastern United States: volume I. N. C. Agric Exp Stn Tech Bull 141:1-538
Mitchell TB (1962) Bees of the eastern United States: volume II. N. C. Agric Exp Stn Tech Bull 152:1-557

Morandin LA, Winston ML (2005) Wild bee abundance and seed production in conventional, organic, and genetically modified canola. Ecol Appl 15:871-881

Murray TE, Fitzpatrick U, Byrne A, Fealy R, Brown MJ, Paxton RJ (2012) Local-scale factors structure wild bee communities in protected areas. J Appl Ecol 49: 998-1008.

Newbold T, Hudson LN, Hill SL, Contu S, Lysenko I, Senior RA, Börger L, Bennett DJ, Choimes A, Collen B, Day J, De Palma A, Diáz S, Echeverria-Londoño S, Edgar MJ, Feldman A, Garon M, Harrison MLK, Alhusseini T, Ingram DJ, Itescu Y, Kattge J, Kemp V, Kirkpatrick L, Kleyer M, Laginha Pinto Correia D, Martin CD, Meiri S, Novosolov M, Pan Y, Phillips HRP, Purves DW, Robinson A, Simpson J, Tuck SL, Weiher E, White HJ, Ewers RM, Mace GM, Scharlemann JP, Purvis A (2015) Global effects of land use on local terrestrial biodiversity. Nature 520:45-50

Noy-Meir I (1995) Interactive effects of fire and grazing on structure and diversity of Mediterranean grasslands. J Veg Sci 6:701-710

Odanaka K, Gibbs J, Turley NE, Isaacs R, Brudvig LA (2020) Canopy thinning, not agricultural history, determines early responses of wild bees to longleaf pine savanna restoration. Restor Ecol 28:138-146

Oksanen J, Blanchet FG, Kindt R, Legendre P, Minchin PR, O'Hara RB, Simpson FL, Solymos P, Stevens MHH, Wagner H (2013) Vegan: community ecology package version 2.0-10. http://cran.r-project.org. Accessed 08 Jan 2020

Polatto LP, Chaud-Netto J, Alves-Junior W (2014) Influence of abiotic factors and floral resource availability on daily foraging activity of bees: influence of abiotic and biotic factors on bees. J Insect Behav 27:593-612

Potts SG, Biesmeijer JC, Kremen C, Neumann P, Schweiger O, Kunin WE (2010) Global pollinator declines: trends, impacts and drivers. Trends Ecol Evol 25: 345-353

Potts SG, Vulliamy B, Dafni A, Ne 'eman G, OToole C, Roberts S, Willmer P (2003a) Response of plant-pollinator communities to fire: changes in diversity, abundance and floral reward structure. OIKOS 101:103-112

Potts SG, Vulliamy B, Dafni A, Ne'eman G, Willmer P (2003b) Linking bees and flowers: how do floral communities structure pollinator communities? Ecology 84:2628-2642

Potts SG, Vulliamy B, Roberts S, O'Toole C, Dafni A, Ne'eman G, Willmer P (2005) Role of nesting resources in organising diverse bee communities in a Mediterranean landscape. Ecol Entomol 30:78-85

Power EF, Stout JC (2011) Organic dairy farming: impacts on insect-flower interaction networks and pollination. J Appl Ecol 48:561-569

Quintero C, Morales CL, Aizen MA (2009) Effects of anthropogenic habitat disturbance on local pollinator diversity and species turnover across a precipitation gradient. Biodivers Conserv 19:257-274

Rehan SM, Sheffield CS (2011) Morphological and molecular delineation of a new species in the Ceratina dupla species-group (Hymenoptera: Apidae: Xylocopinae) of eastern North America. Zootaxa 2873:35-50

Ricketts TH (2004) Tropical forest fragments enhance pollinator activity in nearby coffee crops. Conserv Biol 18:1262-1271

Roberts HP, King DI, Milam J (2017) Factors affecting bee communities in forest openings and adjacent mature forest. For Ecol Manag 394:111-122

Rubene D, Schroeder M, Ranius T (2015) Diversity patterns of wild bees and wasps in managed boreal forests: effects of spatial structure, local habitat and surrounding landscape. Biol Conserv 184:201-208

Schüepp C, Herzog F, Entling MH (2013) Disentangling multiple drivers of pollination in a landscape-scale experiment. Proc R Soc B Biol Sci 281:1-8

Selfridge JA, Frye CT, Gibbs J, Jean RP (2017) The bee fauna of inland sand dune and ridge woodland communities in Worcester County, Maryland. Northeast Nat 24:421-445

Senapathi D, Carvalheiro LG, Biesmeijer JC, Dodson CA, Evans RL, McKerchar M, Morton DR, Moss ED, Roberts SPM, Kunin WE, Potts SG (2015) The impact of over 80 years of land cover changes on bee and wasp pollinator communities in England. Proc R Soc B Biol Sci 282:1-8

Sheffield CS, Pindar A, Packer L, Kevan PG (2013) The potential of cleptoparasitic bees as indicator taxa for assessing bee communities. Apidologie 44:501-510

Steckel J, Westphal C, Peters MK, Bellach M, Rothenwoehrer C, Erasmi S, Scherber C, Tscharntke T, Steffan-Dewenter I (2014) Landscape composition and configuration differently affect trap-nesting bees, wasps and their antagonists. Biol Conserv 172:56-64

Steffan-Dewenter I, Münzenberg U, Bürger C, Thies C, Tscharntke T (2002) Scaledependant effects of landscape context on three pollinator guilds. Ecology 83:1421-1432 
Svensson B, Lagerlöf J, Svensson BG (2000) Habitat preferences of nest-seeking bumble bees (Hymenoptera: Apidae) in an agricultural landscape. Agric Ecosyst Environ 77:247-255

Swanson ME, Franklin JF, Beschta RL, Crisafulli CM, DellaSala DA, Hutto RL Lindenmayer DB, Swanson FJ (2011) The forgotten stage of forest succession: early-successional ecosystems on forest sites. Front Ecol Environ 9:117-125

Taki H, Kevan PG, Ascher JS (2007) Landscape effects of forest loss in a pollination system. Landsc Ecol 22:1575-1587

Taki H, Okochi I, Okabe K, Inoue T, Goto H, Matsumura T, Makino S (2013) Succession influences wild bees in a temperate forest landscape: the value of early successional stages in naturally regenerated and planted forests. PLoS One 8:e56678

Tscharntke T, Gathmann A, Steffan-Dewenter I (1998) Bioindication using trapnesting bees and wasps and their natural enemies: community structure and interactions. J Appl Ecol 35:708-719

Tucker EM, Rehan SM (2018) Farming for bees: annual variation in pollinator populations across agricultural landscapes. Agric For Entomol 20:1-8

Tucker EM, Rehan SM (2016) Wild bee pollination networks in northern New England. J Insect Conserv 20:325-337

Vulliamy B, Potts SG, Willmer PG (2006) The effects of cattle grazing on plantpollinator communities in a fragmented Mediterranean landscape. Oikos 114 $529-543$

Watson JC, Wolf AT, Ascher JS (2011) Forested landscapes promote richness and abundance of native bees (Hymenoptera: Apoidea: Anthophila) in Wisconsin apple orchards. Environ Entomol 40:621-632

Williams NM, Crone EE, Roulston TH, Minckley RL, Packer L, Potts SG (2010) Ecological and life history traits predct bee species responses to environmental disturbances. Biol Conserv 143:2280-2291

Williams NM, Kremen C (2007) Resource distributions among habitats determine solitary bee offspring production in a mosaic landscape. Ecol Appl 17:910921

Winfree R (2010) The conservation and restoration of wild bees. Ann N Y Acad Sci 1195:169-197

Winfree R, Bartomeus I, Cariveau DP (2011) Native pollinators in anthropogenic habitats. Annu Rev Ecol Evol Syst 42:1-22.

Winfree R, Griswold T, Kremen C (2007) Effect of human disturbance on bee communities in a forested ecosystem. Conserv Biol 21:213-223

Zurbuchen A, Cheesman S, Klaiber J, Müller A, Hein S, Dorn S (2010a) Long foraging distances impose high costs on offspring production in solitary bees. J Anim Ecol 79:674-681

Zurbuchen A, Landert L, Klaiber J, Müller A, Hein S, Dorn S (2010b) Maximum foraging ranges in solitary bees: only few individuals have the capability to cover long foraging distances. Biol Conserv 143: 669-676

Zuur AF, leno EN, Walker NJ, Saveliev AA, Smith GM, Walker ZI, Smith S (2007) Mixed effects models and extensions in ecology with R. Springer, New York

\section{Submit your manuscript to a SpringerOpen ${ }^{\circ}$ journal and benefit from:}

- Convenient online submission

- Rigorous peer review

- Open access: articles freely available online

- High visibility within the field

- Retaining the copyright to your article

Submit your next manuscript at $\boldsymbol{\nabla}$ springeropen.com 